\title{
Records of the Children of the Light: The Friends Historical Collection at Guilford College
}

\author{
by Joseph Thomas
}

\section{$R$}

cently, this column introduced readers to the Moravian Archives in Winston-Salem. A Piedmont neighbor to the Archives holds another collection of note related to a religious body: the Friends Historical Collection in Hege Library at Guilford College, in Greensboro, North Carolina. Noted historically for their attention to education, participation in the abolitionist movement and stand for peace, the Friends—also known as Quakers—have lived in North Carolina since the 1660s and kept records of their annual meetings since the 1680s.

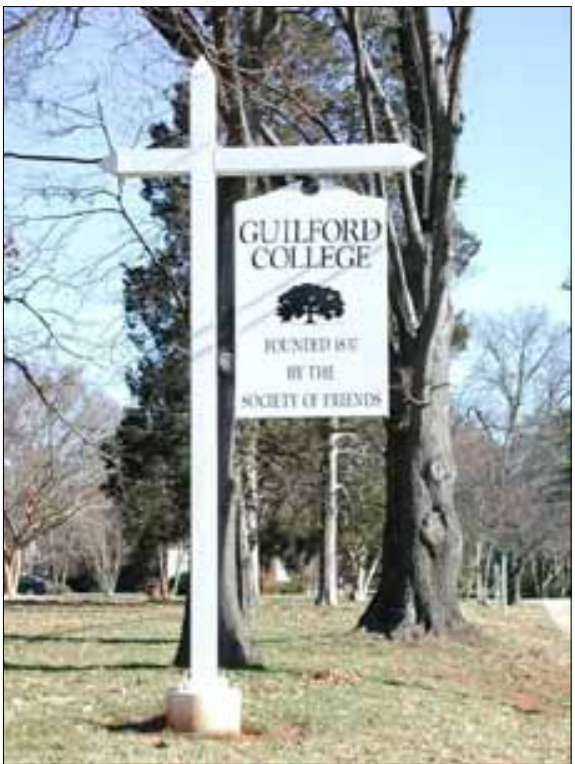

Sign at the intersection of Friendly and New Garden at an entrance to the Guilford College campus. All images courtesy of the Hege Library and Friends Historical Collection.
North Carolina leads the nation in Quaker population, with more than 14,000 of the 113,000 adherents reported in 2000. Now centered primarily in the Piedmont, the state's Friends population is highest in Guilford County, with about 2800; the other counties with significant Friends populations are Forsyth, Yadkin, Alamance, Randolph, Surry, and Alamance, although Perquimans County and others in the area of original Quaker settlement maintain a solid presence. ${ }^{1}$

\section{Background on the Religious Society of Friends}

The Religious Society of Friends dates back to the 1650s in England, and was born of the influences of several influential thinkers, notably George Fox. Fox had an intense experience in June of 1652, during which he believed he experienced God directly-an experience available to anyone, which later developed into the Quaker tenet called the "Inner Light." The name the quickly-burgeoning group of believers chose for themselves, the Society of Friends, comes from Jesus's words to the Apostles: "You are my friends if you do what I command you" (John 15:14). The common name Quakers was originally a derogatory epithet, stemming from one of the many occasions when Fox was in court (he spent six years in prison): reportedly, he told the judge to "tremble at the Word of the Lord," and the judge called him a "quaker." Friends eventually adopted the name as their own.

Central to the Friends' beliefs are the "inner light," equality between men and women and justice for all peoples, the importance of peacemaking, and an emphasis on education. Inner light refers to the inspiration of the Holy Spirit within believers, and Quaker belief in it influenced a profound distrust for creeds, liturgy, and sacraments. Quests for equality and justice have led Quakers to be involved notably in abolitionist and Civil Rights movements, and their peacemaking efforts have remained substantial even today. Friends gatherings for worship are called meetings, and these meetings may be either "unprogrammed" (based on silent waiting and listening to the thoughts of whoever feels the Inner Light's motivation) or programmed (with a simple order of service that often includes a period of silent waiting). ${ }^{3}$ Each congregation has a "Monthly Meeting" for business; nearby monthly meetings are gathered into quarterly meetings, and a group of quarterly meetings is called a yearly meeting. Yearly meetings are autonomous authoritative bodies corresponding to dioceses in episcopal systems. ${ }^{4}$ There are roughly 30 yearly meetings in North America; they may be independent, or may gather with other yearly meetings into an 
overarching association such as the Friends United Meeting (FUM), the Friends General Conference, or the Evangelical Friends International. North Carolina has over ninety monthly meetings, of which the majority are a part of the North Carolina Yearly Meeting affiliated with Friends United Meeting. Others are affiliated with North Carolina Yearly Meeting (Conservative), Southern Appalachian Yearly Meeting, Evangelical Friends International, or Friends General Conference which means that all major branches of modern Quakerism are represented within the state. ${ }^{5}$

By 1656, Friends missionaries came to the New World. Their early years in America were marked by persecution-Mary Fisher and Ann Austin, the first Quaker missionaries to come to these shores, were seized by Boston authorities, imprisoned, and deported back to England. And it got worse. Quakers were imprisoned, beaten, even hanged for their religious beliefs. Mary Dyer was hanged on the $1^{\text {st }}$ of June 1660 on the Boston Common. ${ }^{6}$ It wasn't until the passage of the Act of Toleration (1689) that the persecution of Friends lessened. ${ }^{7}$ William Penn's "Holy Experiment" - Pennsylvania-is perhaps the most wellknown Friends home associated with the early American colonies, but North Carolina's Friends history actually precedes Pennsylvania's 1681 establishment. ${ }^{8}$ George Fox and fellow missionary William Edmondson visited northeastern North Carolina in 1672, and meeting minutes for the state exist as early as 1680 (from Perquimans County). Many of North Carolina's extant historical meeting minutes are gathered with other manuscripts and publications in the Friends Historical Collection at Hege Library, on the campus of Guilford College in Greensboro.

\section{Guilford College and Hege Library}

Guilford College was established by Quakers in 1837 as the New Garden Boarding School, and began conferring degrees in 1889 after reorganization during Reconstruction. . This "New Garden" had been settled by Quakers in the 1750s, in the midst of what had been a "majestic wilderness." This wilderness bore the shock of the nearby Battle of Guilford Courthouse in 1781, with Quakers attending the wounded from both armies, and burying the dead in New Garden Meeting was a stop on the Underground Railroad before the Civil War, and home to a resistance movement against Confederate conscription during the War. ${ }^{10}$ Now home to roughly 2,600 students, Guilford College remains committed to its Quaker roots of wisdom and virtue-contemplation and action —on a campus dedicated to high quality liberal arts education informed by the values of "honesty, compassion, integrity, courage and respect for the individual." 11 What was once "majestic wilderness" has been incorporated into the city of Greensboro, but Guilford College retains its greenery and its sense of quiet: the United States Department of the Interior has recognized the campus as a National Historic District. Guilford College is one of 15 undergraduate Quaker colleges in the United States, and the only one in the South.

Hege Library began in 1908 with a matching grant from Andrew Carnegie, and has grown to encompass about 80,000 square feet of space. Contained within the library are some 250,000

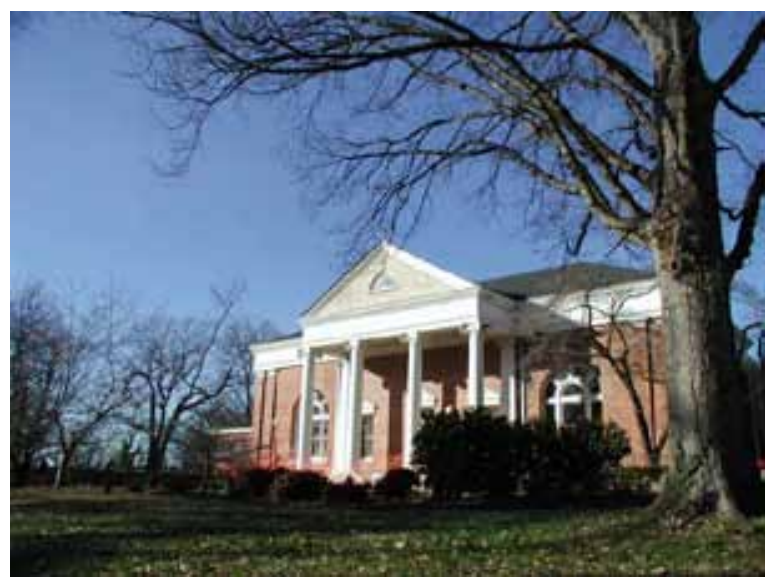

Exterior view of Hege Library on the campus of Guilford College.

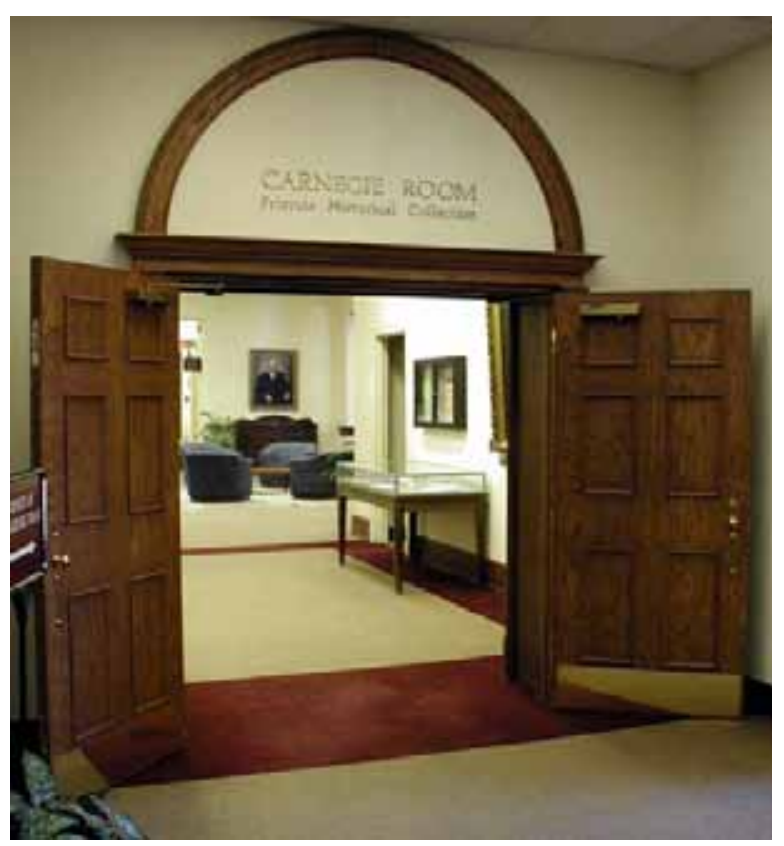

Entrance to historic Carnegie wing of Hege Library which includes the Friends Historical Collection..

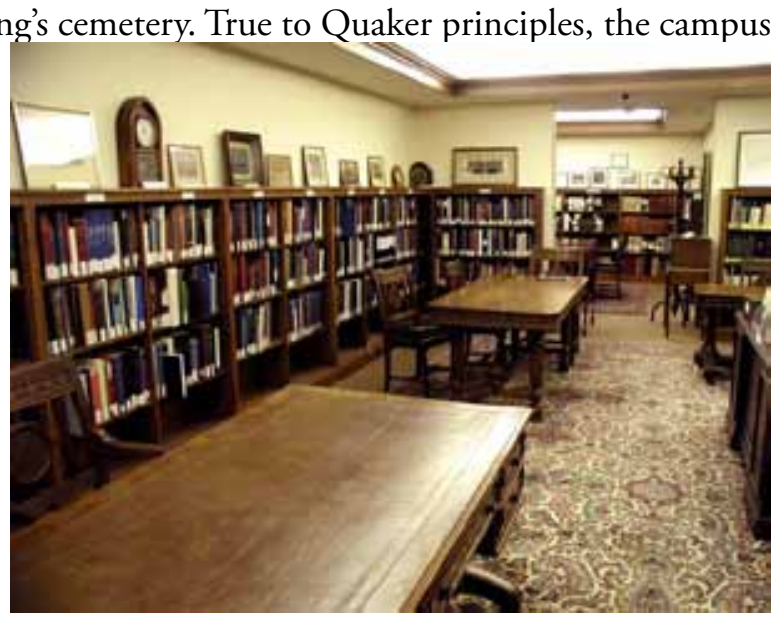

The reading room of the Friends Historical Collection 
items in addition to the Friends Historical Collection, the Friends Center at Guilford College, The Learning Commons, the nine-room Guilford College Art Gallery, and study space for 400 users. $^{12}$

\section{The Friends Historical Collection}

Gathered as a collection in 1937 and renamed in 1980, the Friends Historical Collection pursues as its mission the "acquiring, organizing, preserving and making accessible" published and unpublished materials related to the history of the Religious Society of Friends, with a "special responsibility for comprehensiveness in preserving the intellectual and cultural heritage of Quakerism in the southern United States." 13 The nucleus of the Collection is the records of meetings from North Carolina, an impressive array of more than 300 years of history extending from 1680 to the present. The minutes survived the Civil War in Baltimore, and in the 1880s were returned to North Carolina to be stored in a building owned by the New Garden Boarding School. By 1900 there was a collection custodian, and in 1909, the Yearly Meeting records were incorporated into the library of

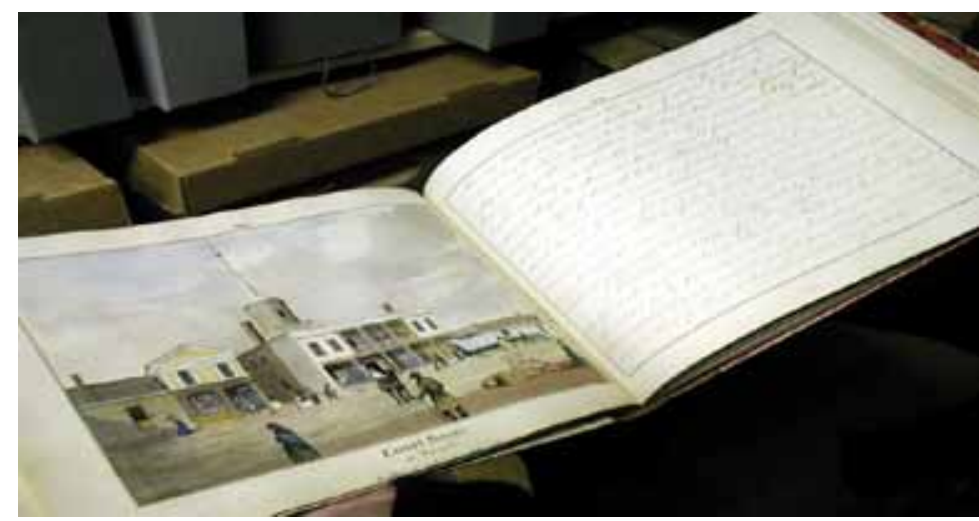

One of a collection of hand illustrated 19th century travel journals kept by John Collins what had become Guilford College. ${ }^{14}$ Although the special collection was organized in 1937, it did not come together in its current form (archives, artifacts, books, manuscripts, and periodicals) in a single location until a 1965 addition to Hege Library. ${ }^{15}$ The Friends Historical Collection retains the records of more than 130 yearly, quarterly, and monthly meetings from the Southeast, including the North Carolina Yearly Meeting (FUM), the North Carolina Yearly Meeting (Conservative), and the Collection also houses the archives of the Southern Appalachian Yearly Meeting and Association, Quaker House of Fayetteville, and the North Carolina Friends Historical Society. The individual meetings retain ownership of their minutes. ${ }^{16}$

In addition to the records of the meetings, the Collection contains nearly 10,000 books, 300 periodicals, and more than 500 manuscripts or manuscript collections related to Quaker thought, history, and genealogy. The Guilford College Archives are also associated with the Friends Historical Collection. And there are other material types in the Friends Historical Collection as well: textiles, which include clothing, blankets, quilts, and samplers, a hunting rifle made by a local Quaker gunsmith, and the original key to the Founders Hall of the New Garden Boarding School. ${ }^{17}$ There are various treasures in the collection, including

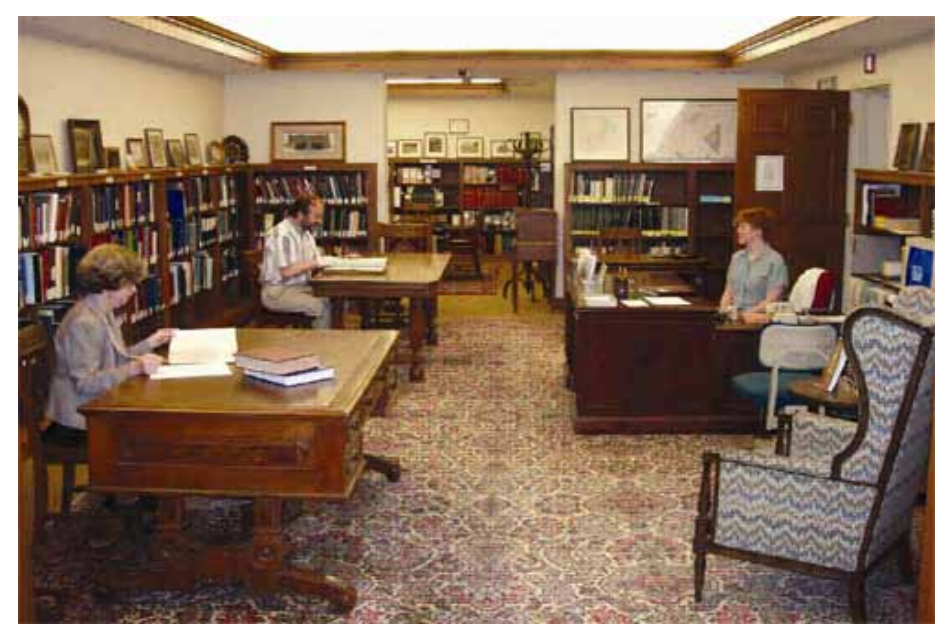

Friends Historical Collection Research Room with staff members Liz Cook, Archives Associate; Tim Cole, part-time NCYM archives assistant; and Gwen Gosney Erickson, Friends Historical Collection Librarian and Archivist the papers of North Carolina Manumission Society and several prominent area families, including the Mendenhalls and the Coxes. One of them may be the earliest poem written in North Carolina: an untitled religious poem by Henry White dated 1698, which was discovered in one of the early meeting minutes. This poem was published by Thomas E. Terrell in the journal Early American Literature in $1983 .{ }^{18}$ Carole Edgerton Treadway's article on the Friends Historical Collection in The Library Quarterly provides additional and greater detail regarding the contents of the Collection. Altogether, the Friends Historical Collection richly documents Quaker family life and local history, genealogy, abolitionist activities, the Friends' emphasis on education (including the education of women), and the history of Guilford College.

Gwen Erickson, Friends Historical Collection Librarian and Guilford College Archivist, has served the Society of North Carolina Archivists as Vice President and President, and is past program chair and current convenor of the Conference of Quaker Historians and Archivists. She is involved with several committees of constituent organizations and serves on the editorial board of The Southern Friend: The Journal of the North Carolina Friends Historical Society. ${ }^{19}$ 
Ms. Erickson works cooperatively with the North Carolina Yearly Meetings and the North Carolina Friends Historical Society in the development of the Friends Historical Collection. Key support is provided by these organizations and donations from individuals to supplement the basic support provided by Guilford College. A federal Library Services and Technology (LSTA) grant through the State Library of North Carolina and the North Carolina - Exploring Cultural Heritage Online (NCECHO) program has permitted the digitization of selected manuscripts, and will enable future projects. The Friends Historical Collection also appears in the Archives Portal of the United Nations Educational, Scientific, and Cultural Organization (UNESCO).

Researchers are welcome to the Friends Historical Collection, which is open to the public during selected hours. Researchers are, however, advised to contact the librarians to verify hours and the availability of staff to assist them. ${ }^{20}$ Staff members are unable to do in-depth research for patrons, but do offer consultations to assist researchers in locating sources and also provide genealogical reference service for a fee. ${ }^{21}$ The Friends Historical Collection provides valuable documentation for the study of the colonial history of the region, antislavery activities, including the Underground Railroad, conscious objection to war, social justice, women's studies, and other topics.

A special thanks goes to Gwen Gosney Erickson for her help in preparing this article.

\section{References}

${ }^{1}$ American Religion Data Archive, "Maps and Reports” and "2000 Membership Report," American Religion Data Archive, http://www.thearda.com/ (August 16, 2006).

${ }^{2}$ Frank S. Mead, Samuel S. Hill, and Craig D. Atwood, Handbook of Denominations in the United States. 12 ${ }^{\text {th }}$ ed. (Nashville: Abingdon Press, 2005), 160.

3 “The Quakers: Children of the Light, An Introduction," Friends United Meeting, http://www.fum.org/about/friends.htm (August 15, 2006).

${ }^{4}$ Ibid., and Mead, Hill, and Atwood, 162.

5 "Quaker Finder" Friends General Conference http://www.quakerfinder.org/ (August 28, 2006). North Carolina Yearly Meeting of the Religious Society of Friends (FUM) http://www.ncym-fum.org/ (August 28, 2006). North Carolina Yearly Meeting (Conservative) of the Religious Society of Friends, http://www.ncymc.org/ (August 28, 2006). 2002 Friends Directory of Meetings, Churches, and Worship Groups in the Section of the Americas and Resource Guide (Friends World Committee for Consultation, Section of the Americas, 2002).

${ }^{6}$ M. Jane Lewis, “Dyer, Mary," American National Biography Online. http://www.anb.org/articles/01/01-00247.html (August 15, 2006).

${ }^{7}$ Mead, Hill, and Atwood, 160.

8 "The Quakers," Ibid.

${ }^{9}$ Alexander R. Stoesen, "Guilford College," Encyclopedia of North Carolina, ed. William S. Powell. Chapel Hill: UNC Press, 2006.

10 "About Guilford," Guilford College. http://www.guilford.edu/about guilford/ (August 25, 2006).

11 “The Strategic Plan for Guilford College 2005-2010," Guilford College, http://www.guilford.edu/about guilford/values/ strategic plan/summary.html (August 25, 2006).

${ }^{12}$ Hege Library, Guilford College, "About the Library," http://www.guilford.edu/about guilford/services and administration/ library/about/index.html (August 25, 2006).

${ }^{13}$ Gwendolyn Erickson, e-mail message to author, August 21, 2006.

${ }^{14}$ Friends Historical Collection, "History of the Friends Historical Collection," Guilford College Friends Historical Collection, http://www.guilford.edu/about guilford/services and administration/library/fhc/history.html (August 28, 2006).

${ }_{15}$ Carole Edgerton Treadway, "Friends Historical Collection, Guilford College," In "Resources for Scholars: Four Quaker Collections in the United States, Part I: Guilford College and Swarthmore College," edited by Thomas D. Hamm. Library Quarterly60 (January 1990): 45.

${ }^{16}$ Friends Historical Collection, "Friends Historical Collection Resources," http://www.guilford.edu/about guilford/services and administration/library/fhc/resources.html (August 28, 2006). 
17 "History of the Friends Historical Collection," Ibid.

${ }^{18}$ Treadway, 49-51.

${ }^{19}$ Gwendolyn Gosney Erickson, "Friends Historical Collection Annual Report 2004-2005” (Friends Historical Collection, Hege Library, Guilford College), 3.

${ }^{20}$ Friends Historical Collection, "Friends Historical Collection General Information,” Guilford College Friends Historical Collection, http://www.guilford.edu/about_guilford/services and_administration/library/fhc/general.html (August 25, 2006).

${ }^{21}$ Friends Historical Collection, "Friends Historical Collection Researcher Services," Guilford College Friends Historical Collection, http://www.guilford.edu/about guilford/services and administration/library/fhc/services.html (August 25, 2006).

\section{Selected Bibliography:}

Farrow, Mildred H. “The History of the Guilford College Library, 1837-1955.” Master's Thesis, University of North Carolina at Chapel Hill, 1959.

Gilbert, Dorothy L. Guilford: A Quaker College. Greensboro, NC: Guilford College, 1937.

Hinshaw, Seth B. The Carolina Quaker Experience 1665-1985. Greensboro, NC: North Carolina Friends Historical Society and North Carolina Yearly Meeting, 1984.

Treadway, Carole Edgerton. "Friends Historical Collection, Guilford College." In "Resources for Scholars: Four Quaker Collections in the United States, Part I: Guilford College and Swarthmore College," ed. by Thomas D. Hamm. Library Quarterly 60 January 1990: 45-56. 